Klaudia Miśkowicz

Uniwersytet Papieski Jana Pawła II w Krakowie

\title{
JEAN-LUCA MARIONA KONCEPCJA IKONY JAKO SPOSÓB NA PRZEZWYCIĘŻENIE ZARZUTÓW PRZECIW RELIGII WYSUNIĘTYCH PRZEZ LUDWIGA FEUERBACHA
}

Próba uporania się z kwestią obrazowania Boga i sposobu radzenia sobie z problemem ujmowania w skończone kategorie tego, co nieskończone, nie jest wymysłem naszych czasów, ale była podejmowana w każdej epoce. Przedstawienia boskości w sztuce bardzo często były po prostu antropomorfizacją - ukazywaniem Boga na obraz i podobieństwo człowieka. Także krytyka religii nie jest wymysłem nowożytnych - można powiedzieć, że wraz z ludzką potrzebą obrazowania tego, co boskie, postępowała potrzeba podkreślania obrazu rzeczywistości boskiej jako transcendentnej, niepojmowalnej i niewyrażalnej.

Takie ujęcie boskości niosło za sobą ukazanie nieadekwatności ludzkiego ujmowania boskości. Za przykład może służyć słynne zdanie Ksenofanesa z Kolofonu: „Gdyby woły i konie lub lwy posiadały ręce i mogły nimi malować i wykonywać dzieła tak jak ludzie, toby konie malowały wizerunki bogów podobne do koni, a do wołów - woły"1. Skoro człowiek nigdy nie widział Boga, nie może wyrazić Go takim, jaki jest, dlatego przedstawia Go sobie na swoje podobieństwo, przypisując $\mathrm{Mu}$ wiele ludzkich cech. Na przykład Bóg Starego Testamentu jest

1 Cyt. za: A. Krokiewicz, Zarys filozofii greckiej, Warszawa 20oo, s. 119. 
Bogiem zazdrosnym (Wj 20, 5), a w Nowym Testamencie Jezus mocno podkreśla, że Bóg jest Ojcem.

Uświadomienie sobie, że wiele religijnych wyobrażeń Boga ma charakter antropomorfizujący, może skłaniać do uznania religii za ludzki wymysł, który nie daje możliwości poznania czy spotkania Absolutu. Nie jest to jednak jedyne możliwe rozwiązanie. W artykule zaprezentowana zostanie krytyka religii przedstawiona przez Ludwiga Feuerbacha, widzącego w niej czysto ludzki konstrukt, opisujący jedynie człowieka, a nie - odsyłający do Boga. Następnie zarysowana zostanie koncepcja idola i ikony Jean-Luca Mariona, która wydaje się mierzyć z krytyką Feuerbacha. W dużym stopniu rozumowanie Mariona koresponduje z argumentami Feuerbacha, jednak Marion wysuwa odmienne wnioski. Pokazuje raczej inną drogę rozwiązania problemu, a co za tym idzie - proponuje nowy sposób patrzenia na religię i relację do rzeczywistości boskiej.

\section{FEUERBACHA KRYTYKA RELIGII}

W swym dziele O istocie chrześcijaństwa Feuerbach przedstawia materialistyczną interpretację religii - neguje istnienie transcendentnej istoty, Boga, który posiadałby wszelkie doskonałości, niemożliwe do osiągnięcia u ludzi. Dla Feuerbacha religia jest „samorozdwojeniem” człowieka: człowiek wymyśla Boga, przypisując mu wszystkie pozytywne cechy ludzkie w stopniu doskonałym, jednocześnie uważając siebie za niezdolnego do ich osiągnięcia. Feuerbach tak opisuje ten mechanizm:

Bóg nie jest tym, czym jest człowiek - człowiek nie jest tym, czym jest Bóg. Bóg jest istotą nieskończoną, człowiek - skończoną; Bóg jest doskonały, człowiek - niedoskonały (...) Bóg jest wszechmocny, człowiek - bezsilny; Bóg jest święty, człowiek - grzeszny².

${ }^{2}$ L. Feuerbach, O istocie chrześcijaństwa, tłum. A. Landman, Warszawa 1959, s. 87. 
Taka wizja zakłada radykalne oddzielenie rzeczywistości ludzkiej od boskiej, fundamentalne przeciwieństwo człowieka i Boga.

Feuerbach pokazuje rolę Boga w życiu człowieka. Uważa, że wykreowanego przez siebie Boga ludzie uczynili gwarantem realizacji własnego pragnienia szczęśliwości, doskonałości czy nieśmiertelności ${ }^{3}$. W rzeczywistości jednak, twierdzi Feuerbach, ludziom tylko wydaje się, że są ograniczeni. Na rzecz tej tezy podaje dwa argumenty. Po pierwsze niektóre ludzkie pragnienia są pragnieniami urojonymi, czyli takimi, które wykraczają poza ludzką naturę. Takimi pragnieniami są na przykład chęć posiadania skrzydeł czy biegania z prędkością światła. Niemożliwość osiągnięcia tych umiejętności nie oznacza żadnego ograniczenia, lecz wynika z braku zrozumienia natury ludzkiej, zgodnie z którą człowiek nie chce nieograniczonej doskonałości, ale doskonałości określonej. Człowiek nie pragnie żyć wiecznie - przekonuje Feuerbach - jednak takie sytuacje jak nieszczęśliwy wypadek czy śmierć dziecka wzbudzają w nim bunt wobec śmierci. Śmierć naturalna, nieobarczona cierpieniem, jest czymś, co człowiek akceptuje ${ }^{4}$.

Drugim argumentem na rzecz tego, że ludzie w rzeczywistości nie są ograniczeni, jest zmiana rozumienia rozwoju: doskonalenia nie powinno się rozpatrywać jedynie w obrębie jednostki, ale całej ludzkości. Człowiek może rozwinąć się tylko w pewnym stopniu, ale ludzkość jako gatunek może doskonalić się w nieskończoność ${ }^{5}$. Dla zobrazowania tezy Feuerbacha użyjmy następującego przykładu. Królowa Kleopatra nie była w stanie zachować swojej urody nienaruszoną, mimo kąpieli w mleku i sprowadzaniu nasyconego minerałami błota z Morza Martwego. Obecnie medycyna estetyczna stosuje potężną liczbę technik, by ludzie jak najdłużej wyglądali młodo; jest możliwe, że za jakiś czas naukowcy znajdą sposób na zatrzymanie procesów starzenia się - w ten sposób

${ }^{3}$ Por. L. Feuerbach, Wykłady o istocie religii, tłum. E. Skowron, T. Witwicki, Warszawa 1953, s. 309.

${ }^{4}$ Por. L. Feuerbach, Wyktady o istocie..., s. 309n.

${ }^{5}$ Por. L. Feuerbach, Wyktady o istocie..., s. 313. 
ludzkość może doskonalić się w nieskończoność. To pokazuje, zgodnie z koncepcją Feuerbacha, że kreowanie wizji zaświatów jako odpowiedzi na potrzebę doskonalenia się po śmierci jest zabiegiem zbędnym doskonalenie następuje bowiem w tym świecie, a jego podmiotem jest cała ludzkość.

Feuerbach jest zdania, że teizm głoszący nicość świata i człowieka wobec Boga jest negacją, a wiara w Boga odziera człowieka z jego godności i wielkości ${ }^{6}$. Pisze:

Ponieważ bóg jest tylko istotą człowieka i przyrody, ale istotą oderwaną, fantastyczną i usamodzielnioną przez wyobraźnię, zatem teizm poświęca życie rzeczywiste, istotę rzeczy i ludzi na rzecz istoty czysto abstrakcyjnej i fantastycznej ${ }^{7}$.

Jest dla niego czymś niezrozumiałym, że to, co istnieje materialnie (a więc w jego ujęciu realnie), jest negowane na rzecz czegoś abstrakcyjnego i nierealnego. Według niego to właśnie ateizm jest czymś pozytywnym, ponieważ przywraca światu i człowiekowi - czyli temu, co realne - znaczenie i godność. Ateizm jest więc afirmacją, teizm - negacją.

Swoją krytykę religii Feuerbach opiera również na przekonaniu, że to człowiek wykreował ideę Boga, przypisując Mu cechy, które sam posiada - w religii człowiek obiektywizuje swoją własną istotę ${ }^{8}$. Skoro Bóg jest uprzedmiotowioną istotą człowieka, to według Feuerbacha teologia w rzeczywistości jest antropologią, a religia to pierwsza samowiedza człowieka9 . Dlatego głoszoną przez teizm ideę miłości do Boga należy przekuć na miłość do człowieka, ponieważ myśląc, że miłujemy Boga, tak naprawdę miłujemy ludzkie cechy, z których wykreowane zo-

${ }^{6}$ Por. L. Feuerbach, Wyktady o istocie..., s. 315.

7 L. Feuerbach, Wykłady o istocie..., s. 316. Feuerbach pisze pojęcie „bóg” małą literą, dlatego zauważyć można nieścisłość między cytowanymi fragmentami a tekstem tego artykułu, w którym pojęcie „Bóg” piszę wielką literą, zgodnie z zasadą, że wielką literą zapisuje się pojęcie określające Boga którejś z religii monoteistycznych, a małą - religii politeistycznych.

8 Por. L. Feuerbach, O istocie chrześcijaństwa, s. 87.

9 Por. L. Feuerbach, O istocie chrześcijaństwa, s. 434. 
stało pojęcie „Bóg”. Przekonanie to zamanifestował Feuerbach słowami: Homo homini Deus est ${ }^{10}$.

Przypomnijmy wniosek wynikający z analizy stanowiska Feuerbacha: istota jego krytyki religii opiera się na spostrzeżeniu, że pojęcie Boga zostało utworzone przez człowieka z wyprojektowania ludzkich cech i nadania im stopnia nieskończoności (Bóg jest nieskończenie dobry, nieskończenie mocny itd.). Stąd wydaje się, że w religii nie istnieje relacja człowieka z Bogiem, ale człowieka z człowiekiem, tj. że człowiek w pojęciu Boga dostrzega tak naprawdę własne odbicie, ale wmawia sobie, że jest to jakaś transcendentna istota. Streszczając myśl Feuerbacha, można powiedzieć, że zarzucił on religii, iż tworzy Boga na obraz i podobieństwo człowieka, utrzymując, że jest odwrotnie.

\section{POJĘCIE IDOLA I KRYTYKA IDOLATRII}

Radykalne poglądy Feuerbacha stały się przedmiotem namysłu wielu filozofów. Współczesny francuski filozof chrześcijański Jean-Luc Marion w swojej książce pt. Bóg bez bycia zdaje się zgadzać z krytyką religii dokonaną przez Feuerbacha.

Tak jak Feuerbach - Marion odrzuca antropomorfizację Boga. Kategorie idola i ikony jawią się jako trafny sposób ukazania błędów wynikających z antropomorfizacji rzeczywistości boskiej, ale także jako sposób wykroczenia poza wnioski, na których zatrzymuje się myśl Feuerbacha. Niemiecki filozof, oskarżając człowieka o projektowanie własnej istoty w ideę Boga, ogłasza właściwie jej upadek. W przeciwieństwie do niego Marion stara się pokazać sposób przezwyciężenia antropomorfizmu. Odrzuca go jako niewłaściwy sposób traktowania religii, ale w jego miejsce proponuje podejście oczyszczone z projektowania rzeczywistości boskiej „na obraz i podobieństwo człowieka”, posługując się pojęciem ikony.

${ }^{10}$ Por. L. Feuerbach, O istocie chrześcijaństwa, s. 434n. 
Marion wychodzi od analizy spojrzenia, które w jego rozważaniach stanowi metaforę ludzkiej świadomości (Marion używa określenia „celowa dążność”). Spojrzenie jest ze swej natury czymś intencjonalnym, co oznacza, że nakierowuje się na przedmiot, szuka czegoś, o co mogłoby się oprzeć. Spojrzenie „chce widzieć”. W kontekście religijności przejawia się to w pragnieniu: „chcę widzieć Boga” ${ }^{11}$. W tym miejscu pojawia się pojęcie idola - zarówno idol, jak i ikona są funkcjami świadomości, czyli sposobami uchwytywania rzeczywistości przez świadomość. Marion stwierdza, że idol i ikona wskazują na sposoby bycia bytów $^{12}$ oraz pełnią różne funkcje. W tej części artykułu omówione zostanie pojęcie idola oraz jego związek z antropomorfizacją boskości, gdyż to właśnie zarzut o antropomorfizację stoi u podstaw krytyki Feuerbacha.

W przypadku idola szukająca przedmiotu celowa dążność przestaje przenikać przez rzeczy, ale zatrzymuje się na jednej z nich. Marion nazywa idola miejscem upadku spojrzenia ${ }^{13}$. Spojrzenie szuka boskości, chce ją ujrzeć, a idol jest efektem zatrzymania spojrzenia, jego konkretyzacją. Spojrzenie, które wcześniej jedynie przenikało przedmioty, na żadnym się nie zatrzymując, nagle przepełnia się blaskiem idola i w końcu to, co widzialne, staje się naprawdę widzialne ${ }^{14}$. Marion pisze, że spojrzenie krzepnie, celowa dążność wyczerpuje się, przestaje szukać i zatrzymuje się - spoczywa na idolu, a przez to staje się „pozbawiona widoków", to znaczy przestaje sięgać dalej, szukać i kierować się na zewnątrz ${ }^{15}$. W tym momencie spojrzenie dostrzega swoją granicę, której wcześniej nie mogło ujrzeć, gdyż ciągle przenikało rzeczy, nie zatrzymując się na żadnej z nich. Teraz, kiedy spojrzenie krzepnie, dostrzegalny staje się zasięg celowej dążności - idol działa tutaj jak zwierciadło, które pokazuje celowej dążności jej zasięg. Można to porównać

\footnotetext{
${ }^{11}$ J.-L. Marion, Bóg bez bycia, tłum. M. Frankiewicz, Kraków 1996, s. 31.

12 Por. J.-L. Marion, Bóg bez bycia, s. 27.

${ }^{13}$ Por. J.-L. Marion, Bóg bez bycia, s. 31.

14 Por. J.-L. Marion, Bóg bez bycia, s. 32.

15 Por. J.-L. Marion, Bóg bez bycia, s. 33n.
} 
również do sondy badającej odległość - idol niejako odbija spojrzenie ku sobie samemu ${ }^{16}$.

Celowa dążność zatrzymana na idolu powraca do siebie, a więc odzwierciedla samą siebie. Nie wykracza już ku boskości, którą chciała ujrzeć, ale próbuje uchwycić ją w tym, co widzialne. Idol jest oznaką tego, że spojrzenie dalej już nie jest w stanie przeniknąć - zatrzymało się bowiem i w pewien sposób wyrzekło się tego, co niewidzialne, chcąc je uchwycić w jakiejś widzialności. Marion porównuje idola do osadu pojawiającego się w winie, kiedy zakończy się proces dojrzewania idol pokazuje efekt zatrzymania się celowej dążności ${ }^{17}$. Jak widać, idol ukazuje zasięg ludzkiego ujmowania boskości, który jest ograniczony. Marion stwierdza, że „idol jest zapisem boskości na miarę ludzkiego spojrzenia" ${ }^{18}$. Bóg według Mariona mierzony jest tylko tym, co ludzkie spojrzenie jest w stanie udźwignąć. Można stwierdzić, że jest to ujmowanie na miarę człowieka, a więc także idol mający uchwycić boskość robi to tylko na miarę człowieka ${ }^{19}$. Dobrze to widać na przykładzie tworzenia pojęcia „Bóg”. Człowiek chce dotrzeć do boskości, przybliża się do niej, ale w pewnym momencie myśl krzepnie i pojawia się pojęcie, które jest jedynie zapisem ludzkiego przybliżania się do niej. To nie Bóg - uważa Marion - jest miarą tego pojęcia, ale celowa dążność. Pojęcie jest więc tworzone na miarę człowieka, a nie na miarę Boga. Marion zgadza się z Feuerbachem, cytując jego stwierdzenie, że „sam człowiek jest prawzorem swojego idola"20.

Powyższe analizy pokazują, że idol więcej mówi o człowieku niż o Bogu - jest bowiem sposobem uwidaczniania przez spojrzenie tego, co niemożliwe do uwidocznienia. Marion podkreśla jednak, że idol „świadczy zawsze o prawdziwym i autentycznym doświadczeniu boskości", ale dzieje się to w taki sposób, że wyznacza zarazem granice

\footnotetext{
${ }^{16}$ Por. J.-L. Marion, Bóg bez bycia, s. 32n.

${ }^{17}$ Por. J.-L. Marion, Bóg bez bycia, s. 50.

${ }^{18}$ J.-L. Marion, Bóg bez bycia, s. 35.

19 Por. J.-L. Marion, Bóg bez bycia, s. 35n.

20 Zob. J.-L. Marion, Bóg bez bycia, s. 37-39.
} 
doświadczenia ${ }^{21}$. Idol nigdy nie dosięga boskości jako takiej, jedynie ujmuje ją na miarę ludzkich możliwości, a wynika to z jego „całkowitej immanencji wobec kogoś, kto go doświadcza”22. Boskość ze swej natury nie może być uchwycona, stąd idol daje jedynie świadectwo jej istnienia - rozpatrywać można ją jednak tylko w tych granicach, do jakich jest w stanie dotrzeć celowa dążność ${ }^{23}$. Marion podkreśla, że idol nie jest błędnym obrazem boskości, lecz raczej ograniczonym funkcjonowaniem celowej dążności - to obraz boskości, jaki wytwarza człowiek. Im bardziej realna jest postać boskości wyrażona w idolu, tym mniej ukazuje Boga ${ }^{24}$.

Na podstawie powyższych ustaleń można zauważyć pewną zbieżność myśli Feuerbacha i Mariona. Skoro idol ograniczony jest do zasięgu celowej dążności i tylko odbija spojrzenie, skoro próbuje ograniczyć to, co nieograniczone, i uczynić widzialnym to, co niewidzialne - to rzeczywiście ma rację Feuerbach, pisząc, że w religii człowiek obiektywizuje swoją własną istotę.

Karol Tarnowski, komentując koncepcję idola i ikony, zauważa tę „morderczo niebezpieczną rolę idola" ${ }^{25}$. Stoi on na skrzyżowaniu objawienia oraz ludzkiej intencji, która owszem, dąży do Nieskończonego, ale robi to tylko w sposób ograniczony i aspektowy - tak idol krystalizuje się w obrazie, a zatrzymanej intencji każe kontemplować nie Nieskończone, ale nią samą. „Bóg pada ofiarą ludzkiej idolatrycznej łapczywości” ${ }^{26}$ komentuje Tarnowski. To właśnie ta „idolatryczna łapczywość” tworzy idole. Obraz staje się ważniejszy od tego, co obrazuje ${ }^{27}$.

\footnotetext{
${ }^{21}$ Por. J.-L. Marion, Bóg bez bycia, s. 52.

${ }^{22}$ J.-L. Marion, Bóg bez bycia, s. 52.

${ }^{23}$ Por. J.-L. Marion, Bóg bez bycia, s. 53.

${ }^{24}$ Por. J.-L. Marion, Bóg bez bycia, s. 53.

${ }^{25}$ K. Tarnowski, Jean-Luc Marion, fenomenolog mitości większej niż bycie, w: J.-L. Marion, Bóg bez bycia, tłum. M. Frankiewicz, Kraków 1996, s. 11.

${ }^{26}$ K. Tarnowski, Jean-Luc Marion..., s. 11.

${ }^{27}$ Por. K. Tarnowski, Jean-Luc Marion..., s. 11.
} 
3. OSKARŻENIE O IDOLATRIĘ JEDNYM Z ARGUMENTÓW PRZECIW RELIGII

W swoich rozważaniach Marion prezentuje ciekawe stanowisko na temat ateizmu. Zauważa, że ateizm opiera się na tym, iż pojęcia mają ograniczony charakter. Negacja polega więc na analizie definicji boskości, a następnie na krytyce tej definicji. Tak było choćby w przypadku ogłoszenia „śmierci Boga” przez Fryderyka Nietzschego. Marion zauważa, że Nietzsche zakłada określenie Boga wyrażające Go w ścisłym pojęciu i tego określenia dotyczy - bardzo często uzasadniona - krytyka. Francuski filozof zdaje się jednak dostrzegać w tym punkcie słabość wszelkich prób negacji Boga: „ateizm pojęciowy może zapewnić sobie dokładność, siłę przekonywania i rzeczowość dowodów tylko dzięki swej wycinkowości"28. Taka negacja dotyczy jednak jedynie konkretnej definicji i nie wykracza poza jej zakres. W związku z tym na przykład przywołana już idea „śmierci Boga” skierowana była w Boga rozumianego w sposób ściśle określony, czyli w idola, ale nie dotykała samej boskości.

Komentując kwestię ateizmu w kontekście myśli Mariona, Tarnowski stwierdza, że „współczesna negacja Boga pochodzi z zastępowania żywego, prawdziwego Boga pewnym, z konieczności regionalnym, skończonym obrazem Boga, który bierze się za rzeczywistość" ${ }^{29}$. Ograniczone pojęcia nie uchwytują boskości jako takiej, a są jedynie skończonymi określeniami wymyślonymi przez człowieka. Opisują więc raczej człowieka i jego dążenia do boskości niż samą boskość.

\section{PRÓBA PRZEZWYCIĘŻENIA KRYTYKI FEUERBACHA}

Zostało już ukazane, jak Marion odnosi się do krytyki Feuerbacha. Koncepcja idola jest w rzeczywistości głosem krytycznym wobec idolatrii i antropomorfizacji Boga. Marion kilka razy cytuje Feuerbacha,

${ }^{28}$ J.-L. Marion, Bóg bez bycia, s. 54.

${ }^{29}$ K. Tarnowski, Jean-Luc Marion..., s. 11. 
zgadzając się, że pojęcia Boga tworzy tak naprawdę człowiek na swój obraz i podobieństwo, będąc pierwowzorem swojego idola ${ }^{30}$. Feuerbach twierdzi, że Bóg to uprzedmiotowiona istota człowieka, Marion natomiast widzi w idolu obraz nie tyle boskości, ile celowej dążności, jej zasięgu i sposobu ujmowania boskości - idol to zapisane w pojęciu przybliżanie się celowej dążności ku boskości ${ }^{31}$.

Dla Feuerbacha odkrycie mechanizmu projekcji, którym posługuje się religia (konstruowanie obrazu Boga z projektowaniem na Niego własnych cech w stopniu doskonałym), oznacza potrzebę obalenia religii i przekształcenia jej w kult człowieka, którego wcześniej czczono pod postacią Boga ${ }^{32}$. Marion nie podąża jednak tą drogą. Dostrzega silne tendencje idolatryczne w religijności i uznaje, że krytyka religii wycelowana w określone pojęcia Boga czasem bywa słuszna. Przyjmując pojęcie Boga jako gwaranta sprawiedliwości, można w sposób uzasadniony negować Jego istnienie, pokazując uczciwych ludzi żyjących w biedzie oraz ludzi nieuczciwych i złośliwych, a jednak bogatych; a akceptacja pojęcia Boga wszechmocnego i dobrego prowadzi niekiedy do przyjęcia postawy ateistycznej, przy uwzględnieniu cierpienia niewinnych ludzi, ludobójstw itd. Marion zauważa, że religia zbyt przywiązana do konkretnych przedstawień Boga i jego cech generuje argumenty przeciw takiemu obrazowi.

W tekście Mariona można jednak zauważyć, że krytyka Feuerbacha nie stanowi dla niego ostatecznego rozwiązania kwestii istnienia Boga, a więc i potrzeby religii. Religia opierać się może na czymś innym niż obrazy Boga wytworzone przez człowieka - francuski myśliciel nie ujmuje tego wprost, jednak na podstawie jego tekstu można wnioskować, że sposobem przezwyciężenia Feuerbachowskiej krytyki może być zmiana podejścia do obrazowania Boga. W tym celu Marion rozwija koncepcję ikony, ukazując inny sposób kontaktu z boskością, który nie byłby ograniczaniem jej i tworzeniem idoli na ludzką miarę.

\footnotetext{
${ }^{30}$ Por. J.-L. Marion, Bóg bez bycia, s. 39, 55.

${ }^{31}$ Por. J.-L. Marion, Bóg bez bycia, s. 38.

${ }^{32}$ Por. L. Feuerbach, O istocie chrześcijaństwa, s. 434.
} 
Feuerbach krytykuje religię, starając się dowieść, że pojęcie Boga wytwarzane jest przez człowieka i że nie ma w Bogu niczego, czego nie można byłoby znaleźć w człowieku czy - mówiąc ściślej - w ludzkości. Dystans, który odczuwał człowiek wobec Boga, spowodowany był tym, że człowiek na drodze projekcji oddawał Bogu swoje najlepsze cechy, a siebie ich pozbawiał. Feuerbach wnioskuje z tego, że Bóg to jedynie wymysł człowieka i nie istnieje rzeczywistość nadprzyrodzona, a tym, co winien czcić człowiek, jest on sam. Podobną uwagę można spotkać u Mariona. Zauważa to Tarnowski, stwierdzając, że idol dąży do zasypania różnicy między tym, co skończone, a tym, co nieskończone ${ }^{33}$. Idol jest po prostu ludzką próbą ujęcia tego, co nieskończone - ale z racji tego, że nieskończone ze swej natury nie jest możliwe do uchwycenia w ludzkie struktury pojęciowe, idol jest refleksją raczej nad człowiekiem niż Bogiem, a także nie wskazuje żadnego dystansu między rzeczywistością ludzką (skończoną) a Boską (nieskończoną). Jednak człowiek religijny nie jest skazany na idole. Religia może opierać się na zupełnie innym sposobie kontaktu z boskością, a sposób ten nie ogranicza tego, co nieskończone, i nie próbuje dostosować tego do ludzkich kategorii. To właśnie ikona - referuje Tarnowski - ukazuje ten jedyny wymiar, w którym możemy spotkać Boga: wymiar dystansu³.

A czym jest ikona? Pojęcie ikony przedstawia Marion, kontrastując je z pojęciem idola. Świadomość działa w ten sposób, że nakierowuje się intencjonalnie na swój przedmiot. W przypadku idola - intencja pochodzi właśnie od świadomości. W przypadku ikony jest odwrotnie - Marion stwierdza, że to ikona spogląda na nas, bo to od niej w tym przypadku pochodzi celowa dążność ${ }^{35}$. Jak idola można porównać do zwierciadła odbijającego naszą celową dążność i ukazującego jej zasięg, tak w przypadku ikony to człowiek jest widzialnym zwierciadłem niewidzialnego - celowa dążność pochodzi bowiem od ikony. Marion pisze: „Widzialny idol nie jest już niewidzialnym zwierciadłem naszego spojrzenia, lecz

\footnotetext{
${ }^{33}$ Por. K. Tarnowski, Jean-Luc Marion..., s. 12.

${ }^{34}$ Por. K. Tarnowski, Jean-Luc Marion..., s. 12.

${ }^{35}$ Por. J.-L. Marion, Bóg bez bycia, s. 42.
} 
nasza twarz jest widzialnym zwierciadłem niewidzialnego"36. W przypadku ikony nie tyle my oglądamy, co jesteśmy oglądani - i dopiero wtedy możemy oglądać, kiedy najpierw jesteśmy oglądani ${ }^{37}$.

W ikonie, inaczej niż w idolu, widzialność i niewidzialność współistnieją ze sobą. Niewidzialne ukazuje się tutaj w takiej postaci, która nie powoduje zatrzymania spojrzenia w czymś widzialnym. W idolu można dostrzec wyraźną granicę między tym, co widzialne, i tym, co niewidzialne; w przypadku ikony widzialne nie przestaje odsyłać do niewidzialnego, a niewidzialne nie zostaje odtworzone w widzialnym, ale pozostaje niewidzialnym $^{38}$. Ikona nie jest zatrzymaniem się na czymś widzialnym, ale to nieskończone odsyłanie do źródła. Dzięki temu odsyłaniu spojrzenie nie ma możliwości zakrzepnięcia i dokonania ograniczenia rzeczywistości boskiej. Marion wyjaśnia: „Ikona wzywa spojrzenie do przechodzenia samego siebie i niekrzepnięcia nigdy w czymś widzialnym, ponieważ widzialne występuje tutaj tylko ze względu na niewidzialne" ${ }^{\prime 3}$. W ten sposób uniknąć można bałwochwalstwa, czyli czczenia czegoś, co nie jest boskością, ale także powstrzymuje to człowieka przed antropomorfizacją, czyli ograniczaniem boskości do kategorii, które stosuje się wobec człowieka.

Idol mierzy boskość zasięgiem celowej dążności człowieka, natomiast dla ikony nie ma innej miary niż jej własna, która jest nieskończona i niezmierzona. Nie zatrzymując spojrzenia, ikona umożliwia człowiekowi kontakt z tym, co nieskończone, ale w taki sposób, że człowiek nigdy nie jest w stanie poznać granicy swojego spojrzenia - kontakt z boskością to raczej kontemplacja niż oglądanie ${ }^{40}$.

Taki opis ikony pozwala spojrzeć na świadomość człowieka wierzącego w inny sposób, niż przedstawia to Feuerbach. Wydaje się, że Marion chce pokazać, iż w przypadku idola krytyka Feuerbacha rzeczywiście

\footnotetext{
${ }^{36}$ J.-L. Marion, Bóg bez bycia, s. 46.

37 Por. J.-L. Marion, Bóg bez bycia, s. 45n.

${ }^{38}$ Por. J.-L. Marion, Bóg bez bycia, s. 39-41, 43.

${ }^{39}$ J.-L. Marion, Bóg bez bycia, s. 41.

${ }^{40}$ Por. J.-L. Marion, Bóg bez bycia, s. 44.
} 
jest słuszna. Idol nie jest tak naprawdę dotarciem do boskości, ale próbą uchwycenia jej w czymś widzialnym - próbą nieudaną, ze względu na niemożliwość ujęcia czegoś nieujmowalnego i ograniczenia czegoś nieograniczonego. Jednak idol nie jest jedynym sposobem, w jaki może przejawiać się doświadczenie religijne - zdaje się twierdzić Marion. Koncepcja ikony pozwala uniknąć zarzutów sformułowanych przez Feuerbacha. Celowa dążność pochodzi tutaj ze strony ikony, a więc nie może być mowy o tym, że to człowiek kreuje Boga. Ponadto kategoria ikony pozwala uniknąć zamykania niewidzialnego w tym, co widzialne - niewidzialne pozostaje niewidzialnym, a wszelkie próby zrozumienia i ujęcia są niemożliwe. W przypadku ikony zarzut o antropomorfizację wydaje się niesłuszny: ikona bowiem nie rości sobie prawa do przedstawiania i uwidaczniania boskości, stanowi jedynie dla spojrzenia pewnego rodzaju „trampolinę”, która pozwala dotrzeć do Niewidzialnego, pozbywszy się ludzkich kategorii.

Wydaje się, że ikona nie pozwala patrzeć na Boga jak na kogoś podobnego do człowieka, a tylko nieskończenie doskonalszego, lecz daje do Niego dostęp jako do absolutnie innego i niemożliwego do uchwycenia - ikona nie zaciera bowiem dystansu między rzeczywistością ludzką (skończoną) a boską (nieskończoną). Miarą ikony jest jedynie jej własna miara, a to oznacza, że w żaden sposób nie da się zredukować rzeczywistości boskiej do ludzkiej, jak chciałby tego Feuerbach. Nie jest tak, że Bóg to zbiór najlepszych cech człowieka podniesionych do nieskończoności - człowiek nie może być miarą Boga. Bóg jest Swoją własną miarą.

Filozoficzna refleksja Feuerbacha rzuciła wyzwanie religii. Sprowadzając religię do idolatrii, a Boga do idola, Feuerbach doszedł do wniosku, że udało mu się zrekonstruować teizm. Odpowiedź Mariona nie neguje wysiłków Feuerbacha, ale równocześnie broni religii i człowieka, pozwalając mu żywić nadzieję, że jego poszukiwanie Boga nie jest daremne i nie stanowi formy samooszukiwania się czy samouwielbienia. W miejsce idola - symbolu poznawczych ograniczeń człowieka zamykającego Boga w ciasnych horyzontach ludzkiej percepcji, który jest ostatecznie tylko ludzkim tworem i ekstrapolacją cech swego twór 
Marion stawia ikonę, która nie jest wytworem ludzkich kategorii ani nie poddaje się im. Ikona odsyła do głębszej, niepojętej rzeczywistości, wymykającej się rozumowemu poznaniu.

Analizy Mariona, jeżeli są trafne, nie tylko pozwalają spojrzeć na Boga bez ryzyka popadnięcia w idolatrię i antropomorfizację, ale też ukazują słabość ateizmu. Ateizm bowiem, skupiając się na zwalczaniu określonych pojęć i obrazów Boga, a więc określonych idoli (wytworów ludzkiego umysłu), nie sięga Boga, który takim wytworem nie jest.

\section{JEAN-LUC MARION'S CONCEPTION OF ICON AS A WAY OF OVERCOMING LUDWIG FEUERBACH'S ARGUMENTS AGAINST RELIGION}

SUMMARY

The issue of the article is to present Jean-Luc Marion's conception of idol and icon as an answer to Ludwig Feuerbach's objections against religion. Feuerbach believed religion is a figment of men that shows the truth about human being, not about God. According to Feuerbach, the idea of God is an objectified essence of human being. Marion partially agrees with Feuerbach: the category of idol shows that religious acts do not grasp God but shows narrowness of human abilities. But it is not the only way of relation to divinity. In the place of the idol Marion proposes to put an icon which does not submit to narrowness of human categories and because of that it can reach a deeper, noncomprehensible realm.

KEYWORDS

Ludwig Feuerbach, Jean-Luc Marion, critics of religion, idol and icon 


\section{BIBLIOGRAFIA}

Feuerbach L., O istocie chrześcijaństwa, tłum. A. Landman, Warszawa 1959. Feuerbach L., Wykłady o istocie religii, tłum. E. Skowron, T. Witwicki, Warszawa 1953.

Krokiewicz A., Zarys filozofii greckiej, Warszawa 2000.

Marion J.-L., Bóg bez bycia, tłum. M. Frankiewicz, Kraków 1996.

Tarnowski K., Jean-Luc Marion, fenomenolog mitości większej niż bycie, w: J.-L. Marion, Bóg bez bycia, tłum. M. Frankiewicz, Kraków 1996. 